\title{
THE IMPACT OF SHEARING AND FLEXIBILITY OF CULTIVATOR TINES ON THE VERTICAL FORCES VALUE
}

\author{
Zygmunt Owsiak $^{\mathrm{a}^{*}}$, Krzysztof Lejman ${ }^{\mathrm{a}}$, Krzysztof Pieczarka ${ }^{\mathrm{a}}$, Tomasz Sekutowski ${ }^{\mathrm{b}}$ \\ ${ }^{a}$ Institute of Agricultural Engineering, Wroclaw University of Environmental and Life Sciences \\ ${ }^{\mathrm{b}}$ Institute of Soil Science and Cultivation - in Puławy \\ ${ }^{*}$ Corresponding author: e-mail: zygmunt.owsiak@upwr.edu.pl
}

\begin{tabular}{|c|c|}
\hline ARTICLE INFO & ABSTRACT \\
\hline $\begin{array}{l}\text { Article history: } \\
\text { Received: December } 2017 \\
\text { Received in the revised form: } \\
\text { February } 2018 \\
\text { Accepted: April } 2018\end{array}$ & $\begin{array}{l}\text { The paper presents the outcomes of the research on the impact of } \\
\text { shearing depth and flexibility of cultivator tines with cultivator points } \\
\text { on the value of vertical forces acting thereon. The object of the re- } \\
\text { search consisted in "S" tines with the flexibility coefficient of } 0.0061 \text {; } \\
0.0711 ; 0.0953 \text { and } 0.1406 \mathrm{~m} \cdot \mathrm{kN}^{-1} \text {. The investigations were carried out }\end{array}$ \\
\hline $\begin{array}{l}\text { Key words: } \\
\text { soil, } \\
\text { cultivator, } \\
\text { vertical forces, } \\
\text { shearing depth, } \\
\text { tine flexibility }\end{array}$ & $\begin{array}{l}\text { in field conditions in sandy clay soil with moisture of } 11.2 \% \text {. The } \\
\text { forces were measured for the assumed shearing depths which were } 5 \text {, } \\
9 \text { and } 13 \mathrm{~cm} \text { at the shearing speed of } 3 \mathrm{~m} \cdot \mathrm{s}^{-1} \text {. A stand for measurement } \\
\text { of forces acting on soil shearing tools in the field conditions was used. } \\
\text { It was found out that the increase of the shearing depth causes a linear } \\
\text { increase of the vertical force, but the force gradient decreases with the } \\
\text { growth of the tine flexibility. Moreover, it was found out that the } \\
\text { increase of the tine flexibility at the beginning causes the increase and } \\
\text { then the decrease of the vertical force regardless the shearing depth. } \\
\text { The impact of flexibility on the vertical force value was described } \\
\text { with the parabola equation. The tines flexibility, at which the highest } \\
\text { value of vertical force may be expected, grows with the reduction of } \\
\text { the shearing depth. }\end{array}$ \\
\hline
\end{tabular}

\section{Introduction}

A trend of partial or absolute abandonment of the energy consuming cultivation treatment, namely ploughing, reported in the recent years, causes the increase of interest in shearing tools equipped with rigid and flexible tines. The use of such tools translates into reduction of the cultivation energy consumption, limits soil degradation and positively influences crop yields (Chen et al., 2005; Rouw et al., 2010). The increase of interest in these tools is reflected in the number of experimental studies (Zhang and Chen, 2017; Przybył et al., 2009) and theoretical studies devoted to this subject (Ucgul et al., 2015; AlKheer et al., 2011). One should also notice that in case of flexible tines which under the impact of forces acting thereon are subjected to elastic deformation, changes in the shearing unit geometry and shearing parameters take place. Due to this variability the authors focus mainly on issues related to modelling of loads, to which rigid tines are subjected. Contrary, in case of empirical research, changes in geometry which take place in the course of shearing with flexible elements, are omitted and the authors focus mainly on the most important 
parameter, which is the shearing resistance that determines the energy consumption of the treatment. However, it should be pointed out that the stability of a tool and its penetration ability depend on the value and vertical forces sense. Moreover, these forces indirectly influence the energy consumption of the treatment because they are shifted to the supporting and coping units as well as to elements of the linkage hitch of tools in a tractor (Shmulevich et al., 2007; Askari et al, 2016; Davoudi et al., 2008). The shearing depth is one of the most important parameters, which should be included in the analysis of loads in the soil-tool system (Al-Janobi et al., 2002; Berntsen et al., 2006; Jafari et al., 2011).

The objective of the paper was determination of the vertical forces values acting on flexible tines of a cultivator in relation to the shearing depth and tines flexibility.

\section{Methodology of research}

The tests were carried out in field conditions in sand clay soil (acc. to PTG 2008). Participation of particular groups of fractions which was determined with BouyoucosCasagrande method in Prószyński modification was: gravel $-4 \%$, sand $-67 \%$, silt $-18 \%$ and clay $-11 \%$. The soil condition was described with the mass moisture, soil cone index, volumetric density and resistance to shearing in the conditions of the border balance. Values of these parameters with standard deviations of measurements (in brackets) were respectively: $11.2 \%(0.5 \%) ; 600 \mathrm{kPa}(70 \mathrm{kPa}) ; 1470 \mathrm{~kg} \cdot \mathrm{m}^{-3}\left(30 \mathrm{~kg} \cdot \mathrm{m}^{-3}\right)$ and $44 \mathrm{kPa}(8 \mathrm{kPa})$. All parameters describing the soil condition during the study were determined in 10 iterations. Preparing soil for tests consisted in ploughing on the depth of $30 \mathrm{~cm}$, scarification with a rototiller and compaction with rollers in depth and on the surface in order to make soil uniform and to level out its surface. Such preparation of soil enables maintaining fixed conditions during the impact of the shearing depth and tines flexibility.

Flexible cultivator tines (Fig.1) ended with a cultivator point with the width of 0.045 and the curvator radius $\mathrm{R}=0.17 \mathrm{~m}$ were the research object. Figure 1 presents a standard cultivator tine (Z3) and three tines (Z1, Z2 and Z4), which were subjected to structural modifications. These modifications were subjected to stiffening of relevant zones of tines $\mathrm{Z} 1$ and $\mathrm{Z} 2$ and reduction of the cross-section of relevant tine zone $\mathrm{Z} 4$. As a result, four tines with a varied value of the flexibility rate were obtained which for tines Z1, Z2, Z3 and Z4 was respectively $0.0061 ; 0.0711 ; 0.0953$ and $0.1406 \mathrm{~m} \cdot \mathrm{kN}^{-1}$. The presented values of elasticity rates were determined by measuring vertical shift of the cultivator point $\left(\mathrm{S}_{\mathrm{x}}\right)$ at the growing value of the vertical force $\left(\mathrm{F}_{\mathrm{x}}\right)$ which was presented in figure 2 . Based on the same studies, it was found out that in the occurring range of variability of the horizontal force, a vertical shift of the cultivation point $\left(\mathrm{S}_{\mathrm{y}}\right)$ is lower than the measurement error of the shearing depth. Structural changes of tines were carried out in such a manner that the changes of the rake angle $(\alpha)$ at the raise of the vertical shift $\left(S_{x}\right)$ were independent from the elasticity of tines. The measurements which were carried out and so introduced structural changes were necessary because the vertical shift which determines the shearing depth and the rake angle according to many authors (Godwin, 2007; Jafari et al., 2011), significantly affect the recorded values of forces. 
The impact of shearing...

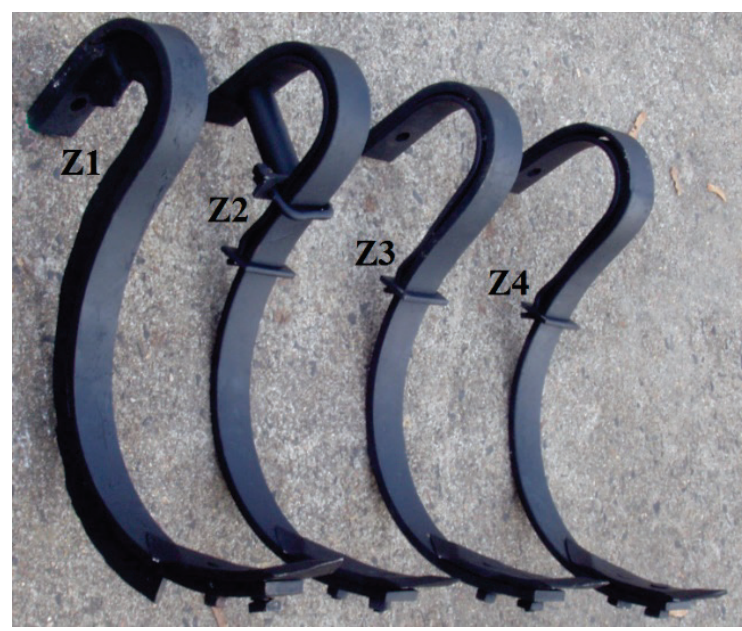

Figure 1. Flexible cultivator tines (Z1, Z2, Z3, Z4) with varied elasticity

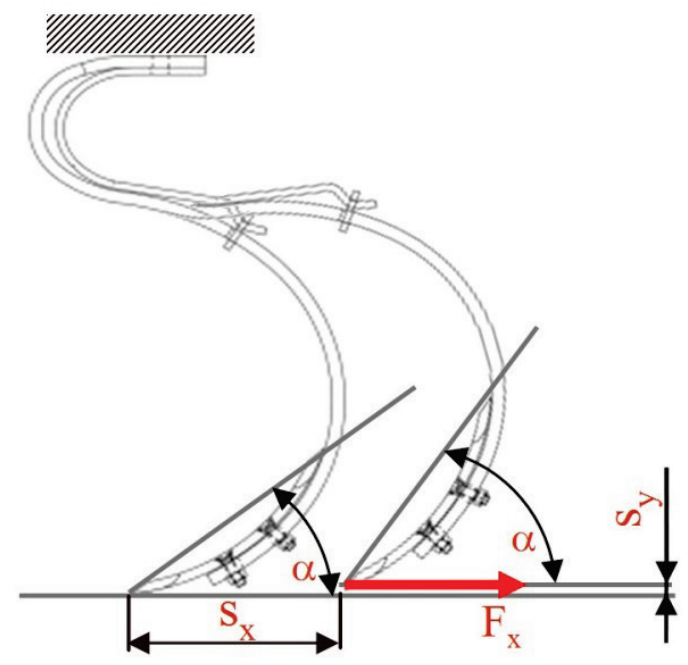

Figure 2. Determination of the horizontal $\left(S_{x}\right)$ and vertical $\left(S_{y}\right)$ deformation and the rake angle $(\alpha)$ at the loading with the horizontal force $\left(F_{x}\right)$

Vertical forces and real shearing depths were measured with a stand for measurement of forces acting on soil shearing tools. The view of the cultivator tine and sensor wheel mounted in the stand were presented in figure 3. The stand enables a simultaneous measurement of the horizontal force, the force moment and real shearing depth. During the analysis, it was assumed that the vertical downward forces are positive forces. 


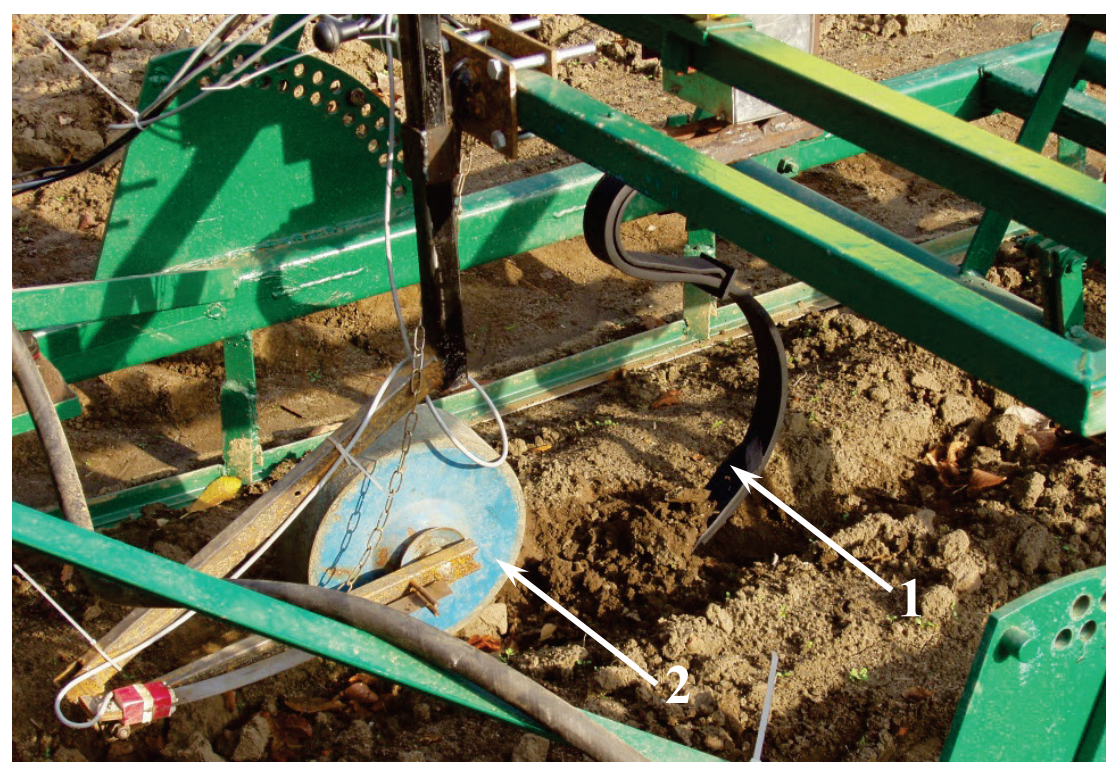

Figure 3. View of cultivator tine (1) and sensor wheel (2) mounted in test stand

The sensor wheel for measuring the real shearing depth moves before the tool (Fig. 3). The registered signals from the depth sensor and the power transducer required thus correlation, which consisted in shifting in time the signals from these sensors. The value of the shift was calculated based on the movement speed and distance between the cultivation point and the point of contact of the wheel with soil measured in the horizontal plain parallel to the movement direction. Additionally, a horizontal movement of the cultivation point caused with the deflection of a tine during shearing was included in this shift. This shift was determined based on the registered value of the horizontal force and the previously calculated index of elasticity of a particular tine.

When planning the experiment it was assumed that the shearing depths will be 5, 9 and $13 \mathrm{~cm}$. However, in case of analysis of the impact of these parameters on the vertical forces values, a full range of its changes was included, which results in the irregularities of the field surface. In such case, the range of the occurring shearing depth was divided into $1-\mathrm{cm}$ long ranges for which the average value of the vertical force was determined. Determination of the impact of tines flexibility required maintenance of the fixed shearing depth. It was obtained by selecting ranges of the registered force for which the shearirng depth was within the ranges $\pm 0.5 \mathrm{~cm}$ in comparison to the assumed depths, i.e. 5,9 and $13 \mathrm{~cm}$. Figure 4 presents the course of the shearing depth with the course of the vertical force correlated therewith and an example of determination of the ranges of vertical force courses for the depth of $11 \mathrm{~cm}$. Determination of relevant ranges of forces was carried out according to the methodology presented in the paper by Lejman et al., (2015). The assumed procedures of correlation in the courses of forces and depths, and selecting ranges of the vertical forces courses in relation to the real shearing depth enable minimization of measurement errors resulting from irregularities of the field surface. This irregularity determines variability of 
The impact of shearing...

the shearing depth which according to many authors (Sánchez-Girón et al., 2005; Berntsen et al., 2006), is one of the most important factors that shape the values of forces acting on the tools.

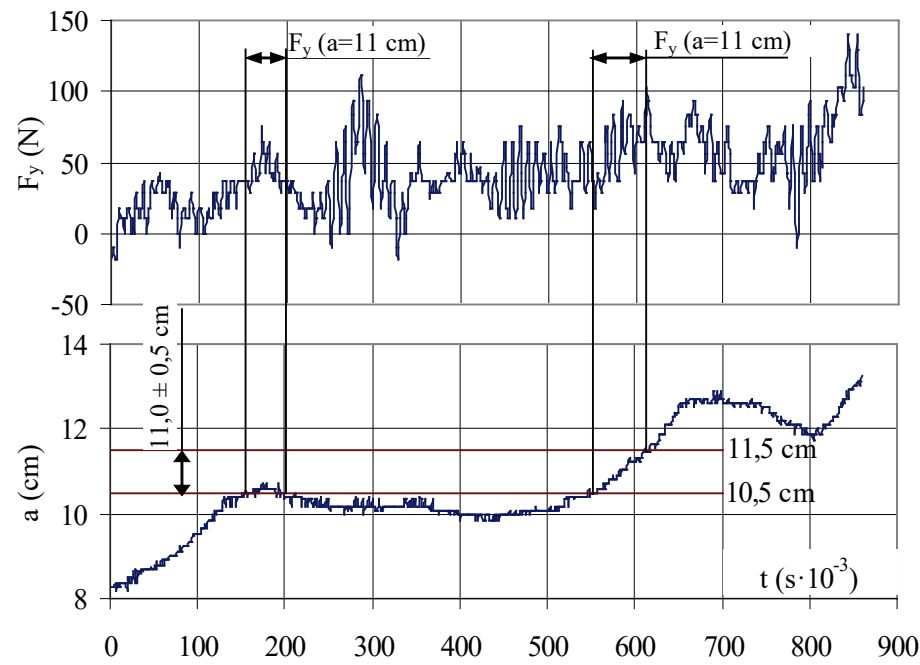

Figure 4. Exemplary courses of vertical forces $\left(F_{y}\right)$ and shearing depth $(a)$ in time $(t)$ and manner of determination of force course ranges for depth of $11 \mathrm{~cm}$

Forces and shearing depths were measured at the shearing speed of $3 \mathrm{~m} \cdot \mathrm{s}^{-1}$ in four independent iterations by registering the values with the frequency of $1000 \mathrm{~Hz}$. Measurement errors of the measured sizes were respectively $5 \mathrm{~N}$ and $1 \mathrm{~cm}$. Statistical development of the obtained results of research was carried out based on the analysis of correlation and regression and the correlation significance tests.

\section{Research results}

The impact of the shearing depth on the vertical force values were described with the straight line equation (fig. 5). One may notice that the increase of the depth causes the increase of the vertical force value regardless the plasticity of a tine. The observed trend confirms the theoretical analyses results and empirical research results obtained by other authors (Ibrahmi et al., 2015; Sánchez-Girón et al., 2005). The increase of the downward forces values at the increase of the shearing depth may be explained with the increase of soil volume and thus its weight acting on the front surface of the tool.

The presented figure shows a higher number of measurement points for each tine, although performance of the research only at three depths was assumed $(5,9$ and $13 \mathrm{~cm})$. It results from the changes of momentary shearing depths, which took place during a single pass, presented in figure 4 showing that the changes in depths are random, which is related to irregularity of the field surface. It enabled selection of pieces of courses of forces regis- 
tered at shearing depths other than the assumed ones. It also results in obtaining a varied number of measuring points in figure 5 and various ranges of the obtained shearing depths for particular tines. The lowest value of the determination coefficient $(0.2241)$ was reported for the tine (Z4) which had the highest value of the flexibility ratio but the correlation between the vertical force and the shearing depth at 18 degrees of freedom is significant for the level of significance of $\alpha<0.035$. For the remaining tines (Z1, Z2 and Z3) the correlation is significant for $\alpha<0.001$ at the number of freedom degrees which are respectively 18 , 18 and 22. Moreover, a general trend of the decrease of the determination coefficient value along with the increase of flexibility may be observed. This trend proves a raising distribution of the registered values of forces together with the registered values of forces which may result from the raising variability of parameters of the tool operation during soil shearing (Berntsen et al., 2006; Lisowski et al., 2016).

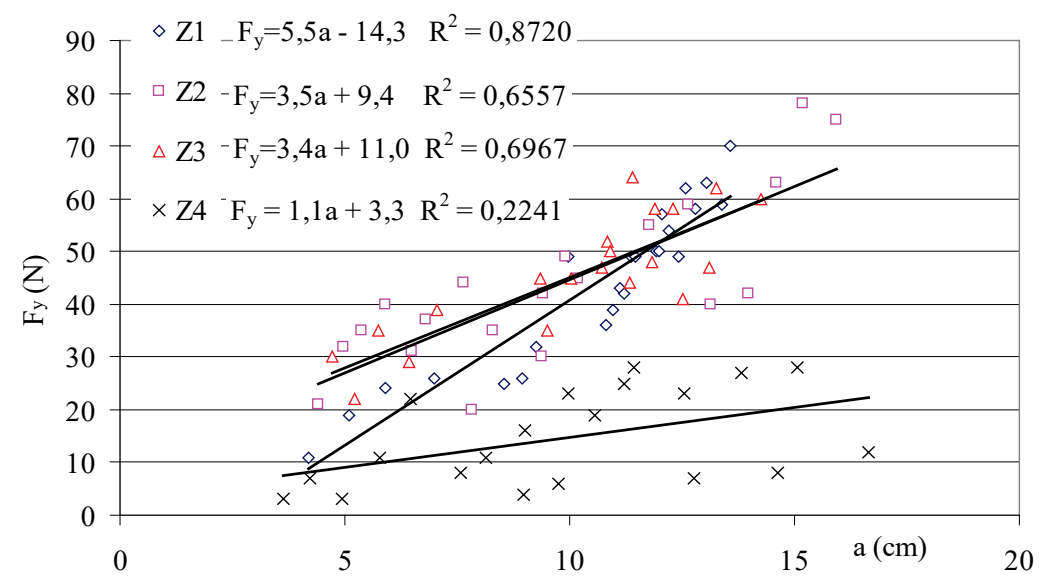

Figure 5. Impact of shearing depth (a) on vertical force value $\left(F_{y}\right)$ for cultivator tines (Z1, Z2, Z3, Z4) with various flexibility

Slopes of equations presented in figure 5 decrease along with the increase of flexibility. Gradients of the vertical force included in the values of these coefficients are significantly negatively correlated at the level of significance of $\alpha=0.05$ with the value of the tine elasticity ratio (fig. 6). Decrease of the vertical force gradient may be explained with the increasing horizontal movements of the cultivator point at the increase of the flexibility of the tine and thus increasing values of the rake angle.

The reported trend confirms the research by Lisowski et al., (2016) who confirmed the occurrence of the higher vertical forces at the soil shearing with rigid tines in comparison to flexible tines. It also confirms the results of the research carried out by Sánchez-Girón et al., (2005) and Jafari et al., (2011) according to which the increase of the rake angle of the tool results in the decrease of the vertical force value. This decrease may be justified with the decrease of the component value of the vertical force related to the movement of soil which loads the front surface of the tool. 
The impact of shearing...

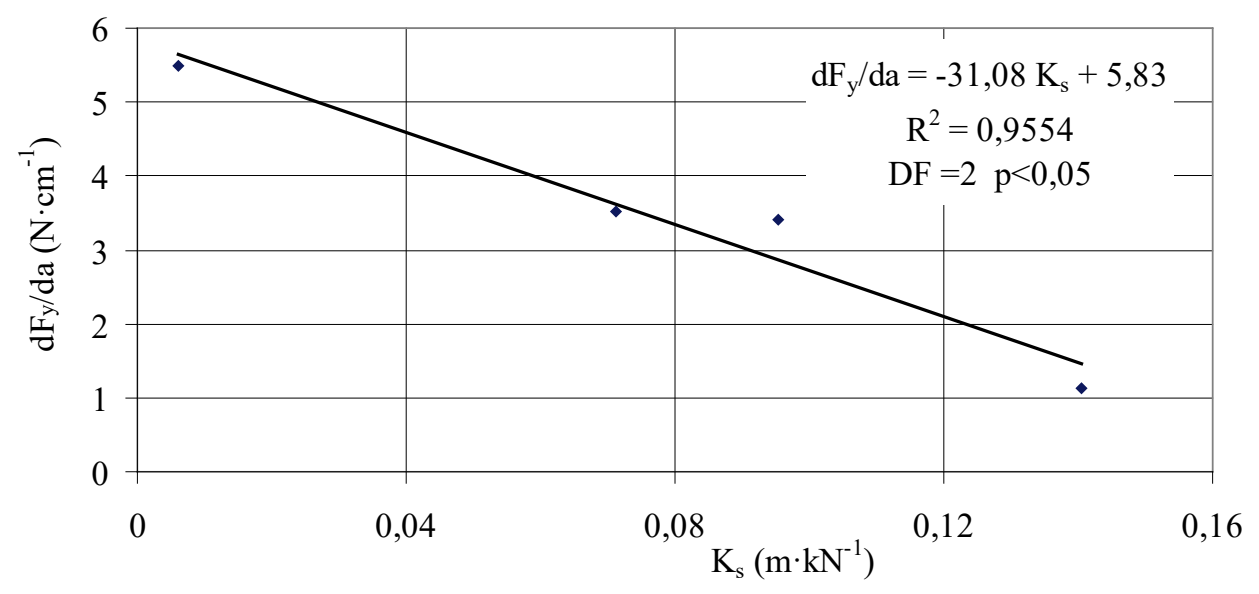

Figure 6. Impact of cultivator tine flexibility $\left(K_{s}\right)$ on value of vertical firce gradient at the increase of depth $\left(d F_{y} / d a\right)$

At the beginning the increase of the tine flexibility causes the increase and then decrease of the value of the vertical force which was presented in figure 7. The obtained courses were approximated with the parabole equation. Values of the ordinates of measurement points result from averaging the values of forces registered for the depths of 5,9 and $13 \mathrm{~cm}$ within the ranges $\pm 0,5 \mathrm{~cm}$. Values of determination coefficient are within 0.9013 to 0.9980 and the correlation coefficient for the depth of 5,9 and $13 \mathrm{~cm}$ at two freedom degrees are significantly respectively at the significance levels $\alpha=0.01 ; 0.02$ and 0.05 .

A non-monotonous nature of the course may be justified with the impact of flexibility of a shearing element on the frequency of free vibrations (Fenyvesi and Hudoba, 2010), which according to the authors positively affect the reduction of the shearing resistance value but only to the specific value of frequency. This information does not directly indicate that the tine flexibility directly affects the vertical forces; however according to AlKheer et al., (2011) and Lisowski et al., (2016) these forces are correlated with the shearing resistance. The decrease of the vertical force may be explained with the increase of the rake angle of the cultivator point, which accompanies the increase of the tine flexibility.

The determined extrema of the functions presented in figure 7 indicate that the coefficient of flexibility that correspond to the maximum values of vertical forces grow at the decrease of the shearing depth. Changes of the maximum shearing depths for corresponding indexes of flexibility at varied shearing depths were determined in figure 7 with the line connecting the obtained extrema. These indexes are for the depths 13,9 and $5 \mathrm{~cm}$ respectively $0.0285 ; 0.0570$ and $0.0636 \mathrm{~m} \cdot \mathrm{kN}^{-1}$. Analysis of variability of the presented extrema and referring to the results of Fenyvesy's and Hudoby's research (2010), a hypothesis may be assumed that between the shearing depth and the value of the flexibility index there is an interaction the consequence of which may be a change in the frequency of free vibrations. 


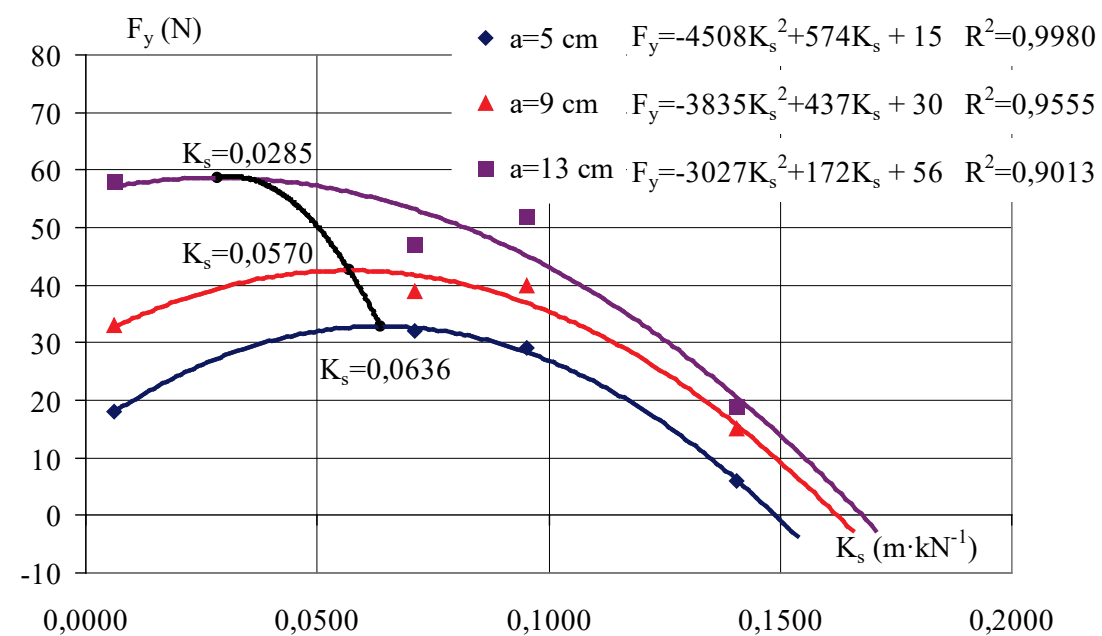

Figure 7. Impact of cultivator tine flexibility $\left(K_{s}\right)$ on vertical force value $\left(F_{y}\right)$ at varied shearing depths (a)

\section{Conclusions}

1. The increase of the tine flexibility causes initially the increase and then the decrease of the value of the vertical force regardless the shearing depth which was approximated with the the second degree parabole equation.

2. Values of coefficient of tines flexibility at which the lowest value of the vertical force is reported decrease along with the increase of the shearing depth.

3. The increase of the shearing depth causes a linear increase of the vertical force regardless the tine flexibility.

4. The increase of the tine flexibility causes a decrease of the vertical force gradient at the increase of the shearing depth.

\section{References}

Al-Janobi, A.A.; Wahby, M.F.; Aboukarima, A.M.; Al-Hamed, S.A. (2002). Influence of chisel plow shank shape on horizontal and vertical force requirements, Agricultural Sciences, 7(1), 13-19.

Al-Kheer, A.A.; Kharmanda, M.G.; El Hami, A.; Mouazen, A.M. (2011). Estimating the variability of tillage forces on a chisel plough shank by modeling the variability of tillage system parameters. Computers and Electronics in Agriculture, 78, 61-70.

Askari, M.; Shahgholi, G.; Abbaspour-Gilandeh, Y.; Tash-Shamsabadi, H. (2016). The effect of new wings on subsoiler performance. Applied Engineering in Agriculture, 32(3), 353-362.

Berntsen, R.; Berre, B.; Torp, T.; Aasen, H. (2006). Tine forces established by a two-level model and the draught requirement of rigid and flexible tines. Soil \& Tillage Research, 90, 230-241.

Chen, Y.; Cavers, C.; Tessier, S.; Monero, F.; Lobb, D. (2005). Short-term tillage effects on soil cone index and plant development in a poorly drained, heavy clay soil. Soil \& Tillage Research, 82, 161-171. 
The impact of shearing...

Davoudi, S.; Alimardani, R.; Keyhani, A.; Atarnejad, R. (2008). A Two Dimensional Finite Element Analysis of a Plane Tillage Tool in Soil Using a Non-linear Elasto-Plastic Model. AmericanEurasian Journal of Agricultural \& Environmental Sciences, 3(3), 498-505.

Fenyvesi, L.; Hudoba, Z. (2010). Vibrating Tillage Tools. Soil Engineering. Springer, Berlin Heidelberg, 31-49.

Godwin, R.J. (2007). A review of the effect of implement geometry on soil failure and implement forces. Soil \& Tillage Research, 97, 331-340.

Ibrahmi, A.; Bentaher, H.; Hamza, E.; Maalej, A.; Mouazen, A.M. (2015). Study the effect of tool geometry and operational conditions on mouldboard plough forces and energy requirement: Part 2. Experimental validation with soil bin test. Computers and Electronics in Agriculture, 117, 268-275.

Jafari, R.; Karparvarfard, S.H.; Hosseini, S.A. (2011). The effect of geometry and motion characteristics of narrow tillage tool on soil disturbance efficiency. Journal of Agricultural Machinery Science, 7(3), 253-258.

Lejman, K.; Owsiak, Z.; Pieczarka, K.; Molendowski, F. (2015). Metodyczne aspekty wyznaczania parametrów przebiegu siły wypadkowej działającej na sprężynowe zęby kultywatora. Inżynieria Rolnicza, 4(156), 69-78.

Lisowski, A.; Klonowski, J.; Green, O.; Świętochowski, A.; Sypuła, M.; Strużyk, A.; Nowakowski, T.; Chlebowski, J.; Kamiński, J.; Kostyra, K.; Mieszkalski, L.; Lauryna, D.; Margielski, J. (2016). Duckfoot tools connected with flexible and stiff tines: Three components of resistances and soil disturbance. Soil \& Tillage Research, 158, 76-90.

Przybył, J.; Kowalik, I.; Dach, J.; Zbytek, Z. (2009). Analiza jakości pracy agregatów do uprawy przedsiewnej. Journal of Research and Application in Agriculture Engineering, 4(54), 62-68.

Rouw, A.; Huon, S.; Soulileuth, B.; Jouquet, P.; Pierret, A.; Ribolzi, O.; Valentin, C.; Bourdon, E.; Chantharath, B. (2010). Possibilities of carbon and nitrogen sequestration under conventional tillage and no-till cover crop farming (Mekong valley, Laos). Agriculture, Ecosystems and Environment, 136, 148-161.

Sánchez-Girón, V.; Ramırez, J.J.; Litago, J.J.; Hernanz, J.L. (2005). Effect of soil compaction and water content on the resulting forces acting on three seed drill furrow openers. Soil \& Tillage Research, 81, 25-37.

Shmulevich, I.; Asaf, Z.; Rubinstein, D. (2007). Interaction between soil and a wide cutting blade using the discrete element method. Soil \& Tillage Research, 97, 37-50.

Ucgul, M.; Fielke, J.M.; Saunders, C. (2015). Defining the effect of sweep tillage tool cutting edge geometry on tillage forces using 3D discrete element modeling. Information Processing in Agriculture, 2, 130-141.

Zhang, X.; Chen,Y. (2017). Soil disturbance and cutting forces of four different sweeps for mechanical weeding. Soil \& Tillage Research, 168, 167-175. 


\section{WPLYW GLĘBOKOŚCI SKRAWANIA I SPRĘŻYSTOŚCI ZĘBÓW KULTYWATORA NA WARTOŚCI SIL PIONOWYCH}

Streszczenie. Przedstawiono wyniki badań wpływu głębokości skrawania i sprężystości zębów kultywatora zakończonych redliczką na wartości działających na nie sił pionowych. Obiektem badań były cztery esowe zęby o wskaźnikach sprężystości 0,$0061 ; 0,0711 ; 0,0953 \mathrm{i} 0,1406 \mathrm{~m} \cdot \mathrm{kN}^{-1}$. Badania przeprowadzono $\mathrm{w}$ warunkach polowych $\mathrm{w}$ glebie o uziarnieniu gliny piaszczystej $\mathrm{i}$ wilgotności $11,2 \%$. Siły mierzono dla założonych głębokości skrawania wynoszących 5,9 i $13 \mathrm{~cm}$ przy prędkości skrawania $3 \mathrm{~m} \cdot \mathrm{s}^{-1}$. Stosowano stanowisko do pomiarów sił działających na narzędzia rolnicze skrawające glebę w warunkach polowych. Stwierdzono, że wzrost głębokości skrawania powoduje liniowy przyrost siły pionowej zagłębiającej, przy czym gradient siły maleje przy wzroście sprężystości zęba. Stwierdzono również, że wzrost sprężystości zęba powoduje początkowo wzrost, a następnie spadek wartości pionowej siły zagłębiającej niezależnie od głębokości skrawania. Wpływ sprężystości na wartość siły pionowej opisano równaniem paraboli. Sprężystości zębów, przy których można się spodziewać najwyższej wartości siły pionowej zagłębiającej, rosną przy spadku głębokości skrawania.

Słowa kluczowe: gleba, kultywator, siły pionowe, głębokość skrawania, sprężystość zęba 